\title{
Molecular docking study of Indonesian phytochemicals as inhibitor of 6-HB formation by binding to HR1 subunit of SARSCOV-2 S2 protein
}

\author{
Jeffry Julianus $^{1^{*}}$, Phebe Hendra ${ }^{2}$, Maywan Hariono ${ }^{1}$, Nico Frederick ${ }^{1}$, Satrio Ardyantoro ${ }^{1}$, \\ Mustofa $^{3}$, Jumina ${ }^{4}$ \\ ${ }^{1}$ Department of Pharmaceutical Chemistry, Faculty of Pharmacy, Universitas Sanata Dharma, \\ Yogyakarta, ${ }^{2}$ Department of Pharmaceutical Pharmacology, Faculty of Pharmacy, Universitas \\ Sanata Dharma, Yogyakarta, ${ }^{3}$ Department of Pharmacology and Therapy, Faculty of Medicine, \\ Public Health and Nursing, Universitas Gadjah Mada, Yogyakarta, ${ }^{4}$ Department of Chemistry, \\ Faculty of Mathematics and Natural Sciences, Universitas Gadjah Mada, Yogyakarta, Indonesia \\ https://doi.org/ 10.22146/ijpther.2392
}

Submitted: 23/08/2021

Accepted : 15/12/2021

Keywords:

COVID-19

in silico screening molecular docking Indonesian phytochemicals $\beta$-carotene

\begin{abstract}
Coronavirus disease 2019 (COVID-19) is still as global pandemic. No officially drugs to treat COVID-19 are available until now. Increasing number of patients and deaths trigger new antiCOVID-19 discovery efforts. In this study, we have conducted in silico screening employing molecular docking for Indonesian phytochemicals. Docking process was performed by employing AutoDock4 software on crystal structure 6VSB. Based on molecular docking results, several compounds had potential as antiCOVID-19 drugs, such as $\beta$-carotene, veramiline, ecliptalbine, betulinic acid, and lupeol. $\beta$-carotene was the most potential compound to treat COVID-19.
\end{abstract}

\begin{abstract}
ABSTRAK
Coronavirus disease 19 (COVID-19) masih menjadi pandemi global. Sampai sekarang belum tersedia obat untuk COVID-19. Dengan jumlah penderita dan kematian yang terus meningkat telah memicu usaha penemuan antiCOVID-19 baru. Pada penelitian ini telah dilakukan skrining in silico dengan metode penambatan molekular terhadap senyawa fitokimia yang terdapat di Indonesia. Proses penambatan dilakukan dengan menggunakan software AutoDock4 pada struktur kristal 6VSB. Berdasarkan hasil penambatan molekuler beberapa senyawa berpotensi sebagai obat COVID-19, seperti $\beta$-karoten, veramilin, ecliptalbin, asam betulinat, lupeol. Di antara senyawa yang diuji, $\beta$-karoten merupakan senyawa yang paling potensial untuk digunakan sebagai obat COVID-19.
\end{abstract}

\section{INTRODUCTION}

The emerging of the severe acute respiratory syndrome coronavirus 2 (SARS-CoV-2) virus at the end 2019 which recognized as coronavirus disease 2019 (COVID-19) caused global pandemic. ${ }^{1-3}$ Several known antiviral drugs have been used to treat COVID-19. ${ }^{4}$ However, the effectiveness these drugs do not meet the expectations. Therefore, the disease still spread quickly from human to human and the number of deaths increase every day. ${ }^{5}$ This situation triggers to discover and develop new COVID-19 drugs which require comprehension about SARSCoV-2 virus structure.

The SARS-CoV-2 virus is a single- 
stranded RNA which consist of 4 structural proteins: spike protein (S), envelope (E), membrane (M), and nucleocapsid (N) ${ }^{6,7}$ Spike proteins are interesting part as treatment and prophylaxis targets of COVID-19. ${ }^{8-10}$ These proteins are located in outer part, consist of S1 and S2 subunit, and involve in SARS-CoV-2 infection process. ${ }^{11}$ The beginning of infection process is formation of a bond between receptor binding domain (RBD) S1 virus with ACE receptor host cell. ${ }^{12}$ This bond activates TM protease serine 2 (TMPRSS2) in host cell to dissociate S1 and S2 subunit. S2 subunit transforms its conformation by inserting fusion peptide (FP). This conformation transformation trigger interaction of Heptad repeats 1 (HR1) and heptad repeat 2 (HR 2) in the S2 subunit to form a six-helix bundle (6-HB) which lead to close proximity between viral and cellular membrane of host cell for fusion and infection. ${ }^{13,14}$

Inhibition of 6-HB formation is a strategy to prevent and treat COVID-19. ${ }^{15}$ The strategy employs a compound which able to bind with HR1 subunit. ${ }^{11,16,17}$ This subunit is a highly conserved. Therefore, it is an interesting target. ${ }^{18}$ Several compounds targeting to bind with HR1 subunit have been designed. 2019-nCoV-HR2P compound is a HR2derived peptide and EK1 demonstrated their ability to bind with HR1 subunit. ${ }^{14,19}$ A lipopeptide derived from EK1, EK1C4, demonstrated stronger bind than EK1 to HR1 subunit. ${ }^{15}$

This study aimed to conducted in silico screening of Indonesian phytochemicals to evaluate its potency as compound to treat COVID-19. In silico process was conducted by employing AutoDock4 as molecular docking software. The crystal structure of 2019-nCoV spike glycoprotein in prefusion state with PDB code 6VSB was protein target. Molecular docking simulations informed us about scoring function of binding energy ( $\Delta \mathrm{G}, \mathrm{Kcal} / \mathrm{mole})$ and ligand-protein interaction. Based on molecular docking result, $\beta$-carotene was the most potential compound to treat COVID-19.

\section{MATERIALS AND METHODS}

\section{Materials}

Crystal structure of 2019-nCoV spike glycoprotein in prefusion state was acquired from protein data bank with PDB ID of 6VSB. ${ }^{9}$ The structures of several phytochemicals were selected as ligands. All molecular docking simulations were done on a Windows 10 machine with Intel ${ }^{\circledR}$ Core i7-8550U (@4.0GHz) as the processors and 8GB of RAM. AutoDock $4^{20}$, MarvinSketch $18.25^{21}$, Discovery Studio 2017 R2 Client ${ }^{22}$ applications were employed in this research.

\section{Structure crystal preparation}

The crystal structure with the PDB id 6VSB was downloaded from PDB website (http://www.rscb.org). Preparation of crystal structure was done by Discovery Studio software to eliminate 2-acetamido-2-deoxy- $\beta$-Dglucopyranose (NAG) molecules, crystal structure subunit B and C (we only used subunit A) discovered in the every $p d b$ file of 6VSB. These crystal structure was saved in $p d b$ files. These file was ready to be used to conduct molecular docking simulations employing AutoDock4 as docking software.

\section{Ligands preparation}

Marvin Sketch 18.25 was employed to draw and undergo a conformational search to find the most sTABLE from 10 seeds of the all phytochemicals. The most sTABLE conformers of the all phytochemicals were saved in 
corresponding $p d b$ files (ligand.pdb) and used for the molecular docking simulations.

\section{Molecular docking simulation}

AutoDock 4 as molecular docking software was employed. Subsequent molecular docking of the all phytochemicals were set as follows. The binding target in the docking configuration file was defined as amino acid number 947 - 1000 (subunit HR1 region) as a center of grid box $62 \times 52 \times$ 125. The grid spacing was set to $1 \AA$. The ligand was docked independently ten times in the binding target of 6VSB. The best pose of each ligand-crystal structure of 6VSB was selected as the pose with the lowest binding energy.

\section{Visualization and interaction of docking result}

Discovery Studio 2017 R2 Client software was employed to visualize the docking result and ligand-crystal structure of 6VSB interactions.

\section{RESULTS}

In silico screening to some Indonesian phytochemicals employing molecular docking method were conducted. Parameter of scoring function of free energy binding ( $\Delta \mathrm{G}, \mathrm{Kcal} / \mathrm{mole}$ ) was used to determine phytochemical potency as antiCOVID-19. Free energy binding value ( $\Delta \mathrm{G}, \mathrm{Kcal} / \mathrm{mole}$ ) represented bond strength between phytochemical with amino acids of crystal structure 6VSB. Compounds which are strongly bond to crystal structure 6VSB had smaller $\Delta \mathrm{G}$ value and vice versa.

Molecular docking result of several phytochemicals was displayed in TABLE 1. $\beta$-carotene had the smallest $\Delta G$ value. This value represented that $\beta$-carotene was strongly bound to HR1 subunit of crystal structure 6VSB. Based on its $\Delta G$ value, $\beta$-carotene was the most potential as antiCOVID-19. The molecular docking result also informed us about potency of another Indonesia phytochemicals as antiCOVID-19. Some of these compounds, such as: veramiline, ecliptalbine, betulinic acid, and lupeol. This was due to difference of $\Delta G$ value of those compounds with $\beta$-carotene less than $0.5 \mathrm{Kcal} / \mathrm{mole}$ and involvement of steroid moiety in interaction with amino acids of HR1 subunit.

Allphytochemicalsforminghydrogen bond and hydrophobic interaction with amino acids of HR1 subunit. The kinds of amino acids involved in hydrogen bond and hydrophobic interaction with each phytochemical were different. We have not been able to determine the key amino acids in HR1 subunit region which had important role to form bond with COVID-19 drug. This was due to there wasn't crystal structure of complex of compound-HR1 subunit that had been successfully crystallized. We argued several amino acids in HR1 subunit which had important role, such as: Leu828; Pro-863; Val-952; Ala-956; His-1058. All of those amino acids were involved in hydrophobic interaction with $\beta$-carotene, resulting the smallest $\Delta G$ value. 
TABLE 1. Scoring function of binding energy $(\Delta G)$ and interaction plots of Indonesian phytochemicals in HR1 subunit.

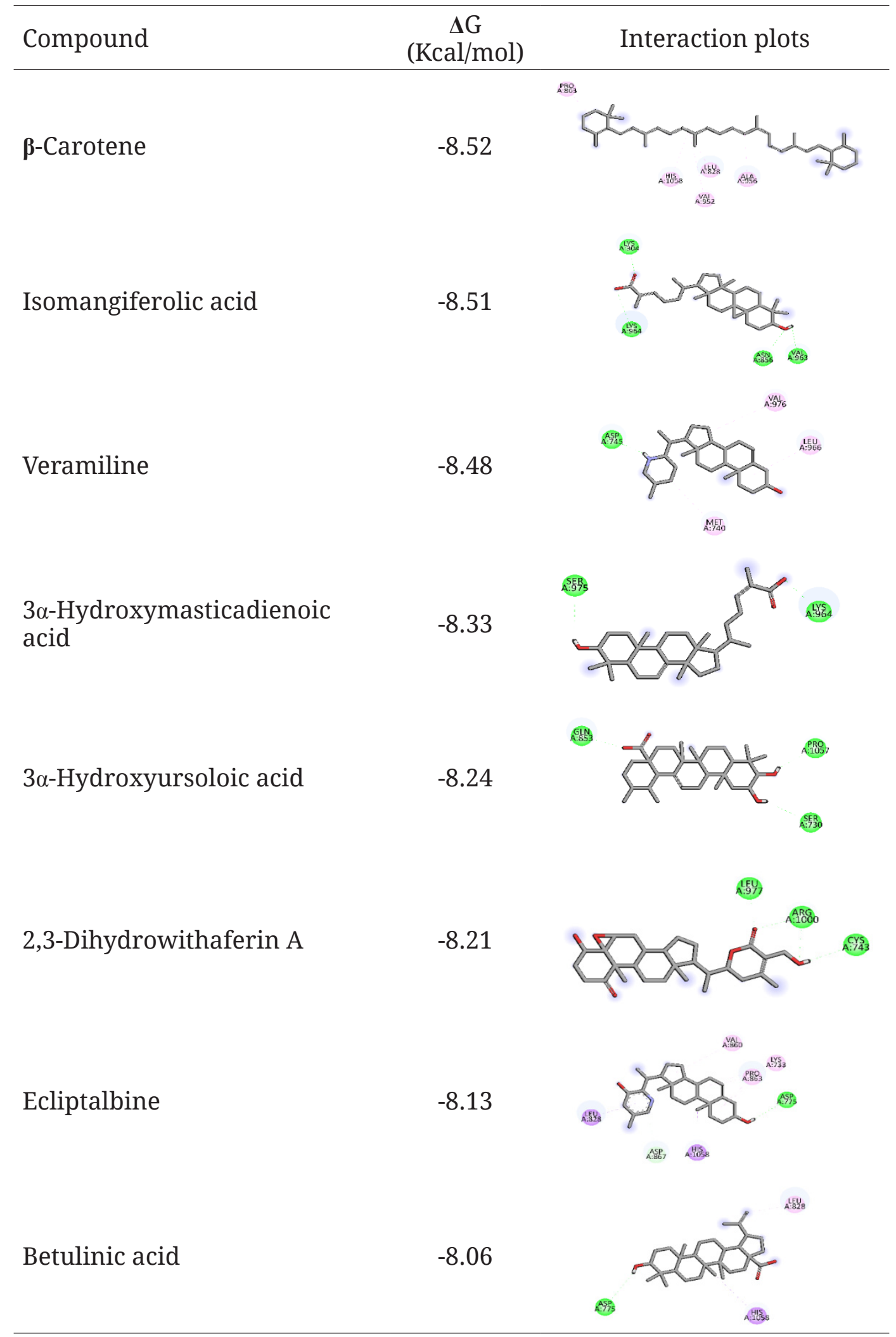


TABLE 1. Scoring function of binding energy $(\Delta G)$ and interaction plots of Indonesian phytochemicals in HR1 subunit (continued.)

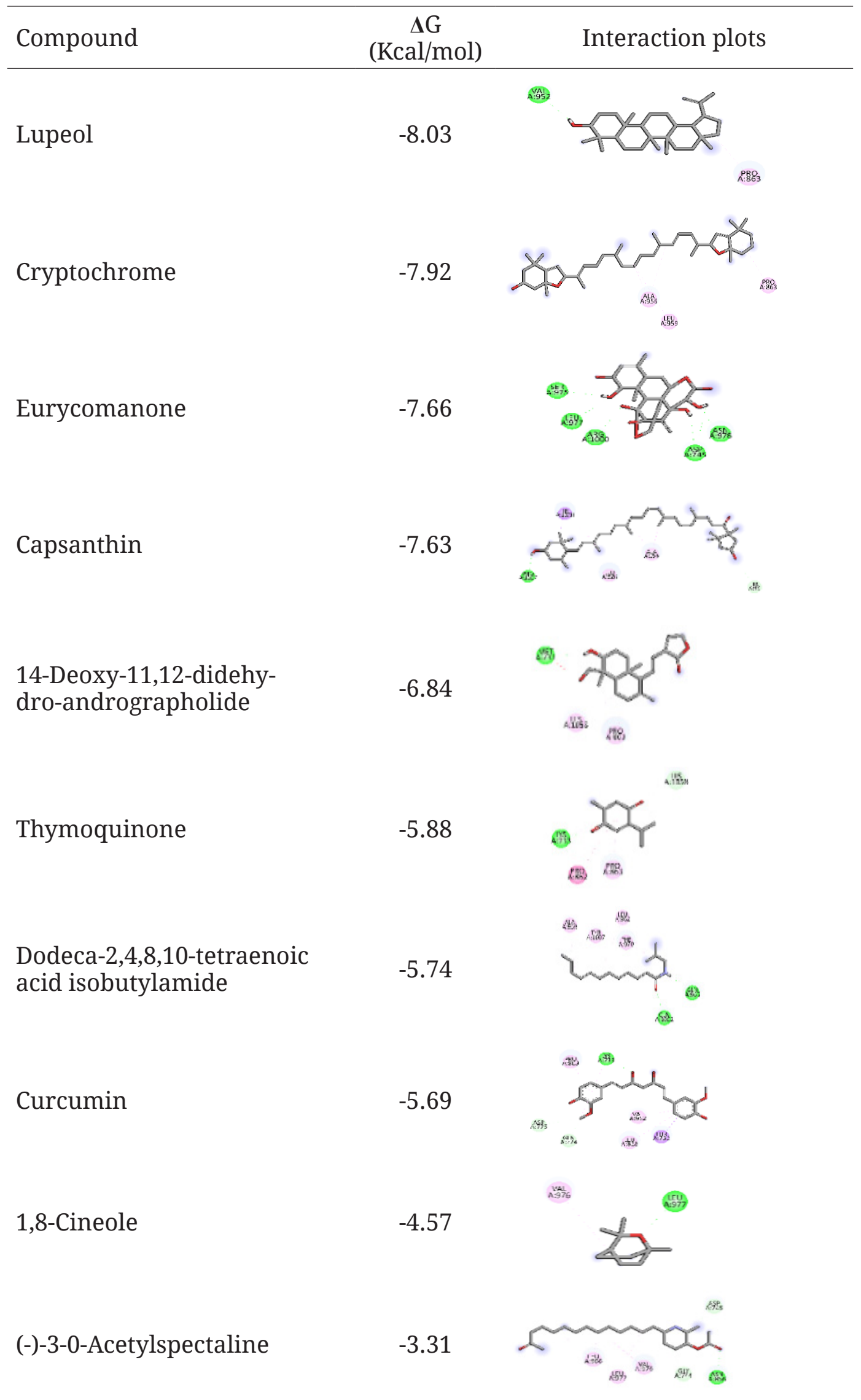

Note: green and light green circle represent hydrogen bonding; purple and magenta circle represent hydrophobic interaction 


\section{DISCUSSION}

Based on molecular docking, $\beta$-carotene was the most potential compound to treat COVID-19. $\beta$-Carotene was a nonpolar long chain molecule with conjugated double bond. Structure of $\beta$-carotene fitted to bind with HR1 subunit. Amino acids in HR1 subunit predominantly hydrophobic. Molecular docking interaction plot displayed $\beta$-carotene bond with HR1 subunit through hydrophobic interaction. This interaction involved $\beta$-carotene's nonpolar planar chain and amino acids Leu-828; Pro-863; Val-952; Ala-956; His1058 of HR1 subunit. All of these amino acids were non polar, except His-1058. Amino acid His-1058 had non polar part which allowed it to bind with $\beta$-carotene's non polar chain. Complex of $\beta$-caroteneHR1 subunit blocked HR2 subunit from binding to HR1 through hydrophobic interaction. This results in 6-HB not being formed. The unavailability of 6-HB prevented SARS-CoV-2 virus from infecting human host cells. The result of this study in line with molecular docking result of lycopene on HR1 subunit. Lycopene was a compound which had similarity structure with $\beta$-carotene and binding with amino acid Leu-1024 of HR1 subunit through hydrophobic interaction. $^{23}$

The others phytochemical, such as veramiline, ecliptalbine, betulinic acid, and lupeol were feasible to study its potency as covid-19 drug. Our argument was based on result of study that EK1C4 compound had better binding activity to HR1 subunit than EK1 compound. The presence of cholesterol which had steroid moiety in EK1C4 compound act as an anchor on target cell membrane to facilitate binding to HR1 subunit. ${ }^{18}$ Structure of EK1C4 and veramiline, ecliptalbine, betulinic acid, and lupeol had similarities in the presence of steroid moiety, so it is possible that these phytochemicals had activity as COVID-19 drug with mechanism of forming bond with HR1 subunit. Our argument was supported by result of interaction plot of molecular docking which displayed veramiline, ecliptalbine, betulinic acid, and lupeol bond with HR1 subunit.

\section{CONCLUSION}

Based on the findings in molecular docking study on crystal structure $6 \mathrm{VSB}, \beta$-carotene was the most potential compound to treat COVID-19 among compounds tested. The mode of action of $\beta$-carotene was to bind to HR1 subunit thereby preventing formation of 6-HB.

\section{ACKNOWLEDGMENT}

No conflict of interests in the preparation of the manuscript was declared.

\section{REFERENCES}

1. Huang C, Wang Y, Li X, Ren L, Zhao $\mathrm{J}, \mathrm{Hu} \mathrm{Y}$, et al. Clinical features of patients infected with 2019 novel coronavirus in Wuhan, China. Lancet 2020; 395(10223):497-506.

https://doi.org/10.1016/S01406736(20)30183-5

2. Zhu N, Zhang D, Wang W, Li X, Yang $\mathrm{B}$, Song J, et al. A Novel Coronavirus from Patients with Pneumonia in China, 2019. N Engl J Med 2020; 382(8):727-33.

https://doi.org/10.1056/NEJMoa2001017

3. Chan JFW, Yuan S, Kok KH, To KKW, Chu H, Yang J, et al. A familial cluster of pneumonia associated with the 2019 novel coronavirus indicating person-to-person transmission: a study of a family cluster. Lancet. 2020; 395(10223):514-23.

https://doi.org/10.1016/S01406736(20)30154-9

4. Li H, Liu SM, Yu, XH, Tang SL, Tang CK. Coronavirus disease 2019 (COVID-19): current status and future perspectives. Int J Antimicrob Agents 2020; 55:1-8.

h t tps://doi.org/10.1016/j. ijantimicag.2020.105951 
5. Wiersinga WJ, Rhodes A, Cheng AC, Peacock SJ, Prescott HC. Pathophysiology, transmission, diagnosis and treatment of coronavirus disease 2019 (COVID-19). JAMA 2020; 324 (8):782-93. https://doi.org/10.1001/jama.2020.12839

6. Lu R, Zhao X, Li J, Yang B, Wu H, Wang $\mathrm{W}$, et al. Genomic characterization and epidemiology of 2019 novel coronavirus: implications for virus origins and receptor binding. Lancet 2020; 395:565-74.

https://doi.org/10.1016/S01406736(20)30251-8

7. Chan JFW, Kok KH, Zhu Z, Chu H, To KKW, Yuan S, et al. Genomic characterization of the 2019 novel human-pathogenic coronavirus isolated from a patient with atypical pneumonia after visiting Wuhan. Emerg. Microbes Infect 2020; 9:221-36. https://doi.org/10.1080/22221751.202 0.1719902

8. Pomplun S. Targeting the SARS-CoV2-spike protein: from antibodies to miniproteins and peptides. RSC Med Chem 2021; 12: 197-202.

https://doi.org/10.1039/D0MD00385A

9. Wrapp D, Wang N, Corbett KS, Goldsmith JA, Hsieh CL, Abiona O. Cryo-EM structure of the 2019-nCoV spike in the prefusion conformation. Science 2020; 367: 1260-3. https://doi.org/10.1126/science.abb2507

10. Sternberg A, Naujokat C. Structural features of coronavirus SARS-CoV-2 spike protein: targets for vaccination. Life Sci 2020; 257:1-7.

https://doi.org/10.1016/j.lfs.2020.118056

11. Huang Y, Yang C, Xu XF, Xu W, Liu SW. Structural and function properties of SARS-CoV-2 spike protein: potential antivirus drug development for COVID-19. Acta Pharmacol Sin 2020; 41: 1141-9.

https://doi.org/10.1038/s41401-020-0485-4

12. Shang J, Wan Y, Luo C, Ye G, Geng Q, Auerbach A. Cell entry mechanisms of SARS-CoV-2. PNAS 2020; 117(21): 11727-34.

https://doi.org/10.1073/pnas.2003138117
13. Bosch BJ, Martina BEE, van der Zee R, Lepault J, Haijema BJ, Versluis C. Severe acute respiratory syndrome coronavirus (SARS-CoV) infection inhibition using spike protein heptad repeat-derived peptides. PNAS 2004; 101(22):8455-60.

https://doi.org/10.1073/pnas.0400576101

14. Xia S, Zhu Y, Liu M, Lan Q, Xu W, Wu $\mathrm{Y}$, et al. Fusion mechanism of 2019nCoV and fusion inhibitors targeting HR1 domain in spike protein. Cell Mol Immunol 2020; 17:765-7.

https://doi.org/10.1038/s41423-020-0374-2 Xia S, Liu M, Wang C, Xu W, Lan Q, Feng S, et al. Inhibition of SARS-CoV-2 (previously 2019-nCoV) infection by a highly potent pan-coronavirus fusion inhibitor targeting its spike protein that harbors a high capacity to mediate membran fusion. Cell Res 2020; 30: 343-55.

https://doi.org/10.1038/s41422-020-0305-x

15. Olivia R, Shaikh AR, Petta A, Vangone A, Cavallo L. D936Y and other mutations in the fusion core of the SARS-CoV-2 spike protein heptad repeat 1: frequency, geographical distribution, and structural effect. Molecules 2021; 26 (2622): 1-13.

h t t p s : // d o i.org / 10.3390 / molecules26092622

16. Ling R, Dai Y, Huang B, Huang W, $\mathrm{Yu} \mathrm{J}, \mathrm{Lu} \mathrm{X}$, et al. In silico design of antiviral peptides targeting the spike protein of SARS-CoV-2. Peptides 2020; 130:1-7.

ht tps://doi.org/10.1016/j . peptides.2020.170328

17. Xia S, Yan L, Xu W, Agrawal AS, Algaissi A, Tseng CTK, et al. A pan-coronavirus fusion inhibitor targeting the HR1 domain of human coronavirus spike. Sci Adv 2019; 5: 1-15.

https://doi.org/10.1126/sciadv.aav4580

18. Liu S, Xiao G, Chen Y, He Y, Niu $\mathrm{J}$, Escalante $\mathrm{CR}$, et al. Interaction between heptad repeat 1 and 2 regions in spike protein of SARSassociated coronavirus: implications for virus fusogenic mechanism and 
identification of fusion inhibitors. Lancet 2004; 363:938-47.

https://doi.org/10.1016/S01406736(04)15788-7

19. Morris GM, Huey R, Lindstrom W, Sanner MF, Belew RK, Goodsell DS, et al. AutoDock4 and AutoDockTools4: automated docking with selective receptor flexibility. J Comput Chem 2009; 30 (16):2785-91.

https://doi.org/10.1002/jcc.21256

20. MarvinSketch, 18.25, ChemAxon (https://www.chemaxon.com)

21. Dassault System BIOVIA. Discovery Studio Visualizer. V.17.2.0. San Diego: Dassault Systems. 2016.

22. Majeed A, Hussain W, Yasmin F, Akhtar A, Rasool N. Virtual screening of phytochemicals by targeting HR1 domain of SARS-CoV-2 S protein: molecular docking, molecular dynamics simulations, and DFT studies. Biomed Res Int 2021; 2021: 1-19. https://doi.org/10.1155/2021/6661191 